\title{
An ethnographic account of a snapshot in Professor Graham Duncan's journey of educational professionalism
}

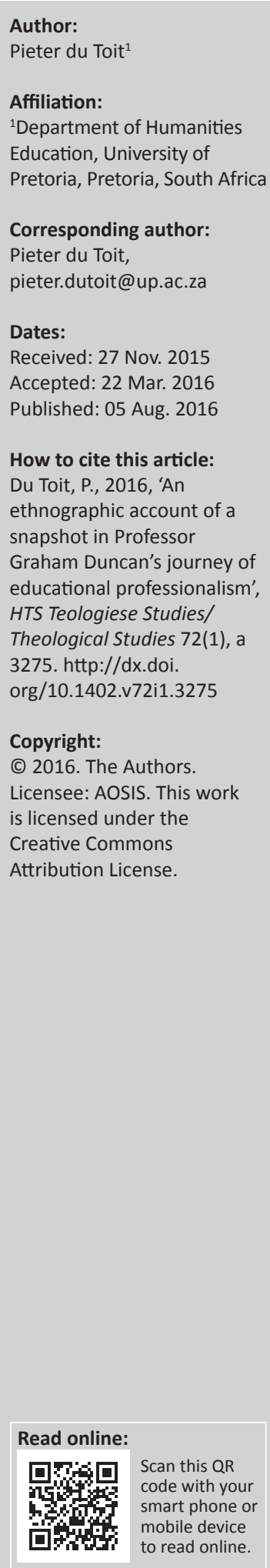

This article takes the form of a meta-reflection on the educational contribution to the wider community of the University of Pretoria made by Professor Graham Duncan. It is but a snapshot of the academic life of a scholar of note. The epicentre of the article revolves around his educational professionalism that emanated from an intrapersonal point of departure.

Through an ethnographic lens that informed my action research over many years, I document my numerous scholarly encounters with my colleague and former student. My meta-reflection is typical of my ontological-epistemological stance, mirroring some of the questions and ways of thinking Professor Duncan as lecturer continuously asked himself. Two main questions are focused on. Ontological: Who is Graham Duncan as scholar of teaching in higher education? Epistemological: What epistemological grounding informs his view of his teaching practice?

As the nature of the article is ethnographic, I drew on texts created by Professor Duncan. These included a drafted article and emails that had been sent to me. I engaged with these texts in such a way that the article has become a living theory and affirmation of his and my educational values regarding facilitating and assessing learning in an innovative fashion. My analysis of his scholarly journey and texts offers rich qualitative data that are reported. The conclusion drawn is that Graham Duncan is an exemplar of a constructivist professional.

\section{Research design and research questions}

I deliberately do not start this article in a traditional way - beginning with an introduction - as it would contradict the nature of the research design it is based on. As scholar of the educationalprofessional development of academic staff, the overarching research design that I follow is action research (McNiff \& Whitehead 2006; Zuber-Skerritt 2000), following an asset-based approach (Du Toit 2012) that is cyclical and continuous. The article reports on a micro-cycle within the research process followed for more than a decade and is narrative in character - a story about an academic at the University of Pretoria, a professor, whom I had the privilege of meeting at a professional level. It tells the story of his educational-professional development journey as I came to know it. For a great part of the journey, I was a co-traveller. The micro-research study complementing and enriching my action research is ethnographic as it is concerned with a specific unit of analysis (Babbie 2013; Mouton 2001), namely the teaching practice of the academic in question. Typical of an ethnographic study is that it concerns itself with issues of social life academic life in this case - at the level of individuals. Therefore, it may be relevant to classify this research study as micro-theory (Babbie 2013). As a qualitative research design, it is also more unstructured (Kumar 2014), which becomes clear in the narrative as the reporting is an account of a journey that was sometimes 'unplanned' - stemming from a self-initiated akademische Wanderlust.

Being the primary participant, I am not passive in making meaning ( $\mathrm{O}^{\prime}$ Leary 2014). Christensen, Johnson and Turner (2014:364) refer to this as 'social "construction" of reality' and the insider's perspective, while Kumar (2014) mentions the importance of increasing the understanding of one's own profession and advancing the professional knowledge base. My reality of which I make meaning while reflecting on my profession is my involvement in the educational-professional development of lecturers - in both a formal and an informal sense.

Fitting this research design is one overarching ontological research question: Who is Professor Graham Duncan?

And one overarching epistemological question is: What is the new meaning of teaching practice Professor Duncan constructed? 
Graham Duncan introduces himself as follows in the title of a drafted article: 'Quis custodiet ipsos guardians?' (Who guards [nurtures] the guardians?). In the sub-title of the conceptualised article, he refers to developing a constructivist approach to learning within the context of ministerial and spiritual formation. Constructivism (Von Glasersfeld 2001) is a value that I hold in terms of the educational-professional development of academic staff in general, and one he holds in terms of all his roles as academic. As investigating my practice by means of action research is founded on constructivist epistemology, I claim that my curriculum development, facilitating and assessing of learning of my students and other roles I have to enact (Department of Education 2002) serve as exemplars for my students enrolled for the Postgraduate Certificate in Higher Education (PGCHE). For the purpose of gathering data for my action research, I use different data sets. Data reported in this article are qualitative in nature. A text analysis of a study manual of the module on Professional Development offers some insight into the purpose of Professor Duncan's academic journey. This purpose is outlined below. I use this excerpt from the set of data with a view to showing how Professor Duncan aligned his scholarship of teaching with the focus on the PGCHE.

The overarching purpose of the PGCHE (University of Pretoria 2015) is the educational-professional development of higher education practitioners. It, inter alia, includes the following:

- Constructing new meaning

- Monitoring one's own professional development

- Facilitating the development of the full potential of students

- Becoming actively involved in one's professional development

- Becoming an independent, life-long learner.

Apart from being the programme coordinator who oversees the implementation of the programme, consisting of nine modules, I am responsible for offering five modules. These include modules on Facilitating Learning, Professional Development and Research Supervision. Other core modules of the programme are Assessment Practice and Curriculum Development.

In terms of Professor Duncan's taking responsibility for curriculum development, the following can be reported. Ministers for whose professional development he took responsibility are expected to fulfil a multitude of roles and become competent in enacting these roles. Therefore, any curriculum that focuses on the professional development of ministers should make provision for a life of service to the community - a real-life context (Slabbert, De Kock \& Hattingh 2009) ministers will encounter on a daily basis, which Professor Duncan embraced as a challenge for his students as well as for himself. His real-life context as a lecturer manifested the highest quality of executing all the roles he had to enact. These roles are set out in the Norms and standards for educators (Department of Education 2002), a policy document that governs all levels of education, including higher education. It includes, inter alia, facilitating of learning, curriculum development, assessment, leadership and scholarship of teaching. Professor Duncan excelled in enacting these roles. This is a claim I make based on evidence from his practice, as McNiff and Whitehead (2006) propose, we do when we as scholarly higher education practitioners need to justify what we and our students - in this case, my former student, Professor Duncan - do.

The following email received from him on 28 June 2010 underscores his commitment to becoming a scholar of teaching and to act as leader who can mentor others:

We are both working from the perspective that, while we acknowledge the important place of research, this needs to be grounded in sound teaching and learning. My own view is that each faculty should identify individuals who can be leaders in this field as well as in research and community engagement and act as resources for the others who do not have these strong points.

As a scholar of teaching exemplifying an innovative practice, he was invited by me to act as respondent in an international research project - a project on peer review - with the University of Macquarie in Australia in 2011. He was also involved in a national project on quality enhancement initiated by the Council of Higher Education (CHE) in 2014 to which he contributed as a member of a task team focusing on 'Enhancing academics as teachers' under the leadership of Professor Manning, Deputy Dean of the Faculty of Health Sciences. This is mentioned here as I was aware of this at the time of execution of the projects and it is in keeping with the ethnographic nature of the research reported in this article.

In a metaphoric sense, I would like to draw on the views of Professor Duncan when he writes about the professional development of ministers, as is explicated in relevant curricula designed for this purpose. When it comes to lecturer professionalism, I would like to use the construct 'formation' that he uses. Lecturers are subjected to the stresses and anxieties of those whom they serve - students and the university community at large. Despite the professional development of ministers that Professor Duncan considers as 'training in the academic domain', he opted for enrolling for the PGCHE, which is innovative in the sense that it combines scholarships of teaching and research. It is practical in all its facets - as represented by the different modules - and offered Professor Duncan real-life challenges that he executed with passion and great success. The fact that he was awarded the qualification Cum Laude is proof of his achievements, although obtaining high marks was never his goal, but rather excellence in what he was doing as lecturer. Figure 1 represents the narrative of his PGCHE journey - attending the graduate ceremony. Visual 2 represents the narrative of his zest for life in general and his academic career in all its dimensions.

In his leadership capacity, he acted as mentor (discipling scholar) to other colleagues in his department and faculty - 


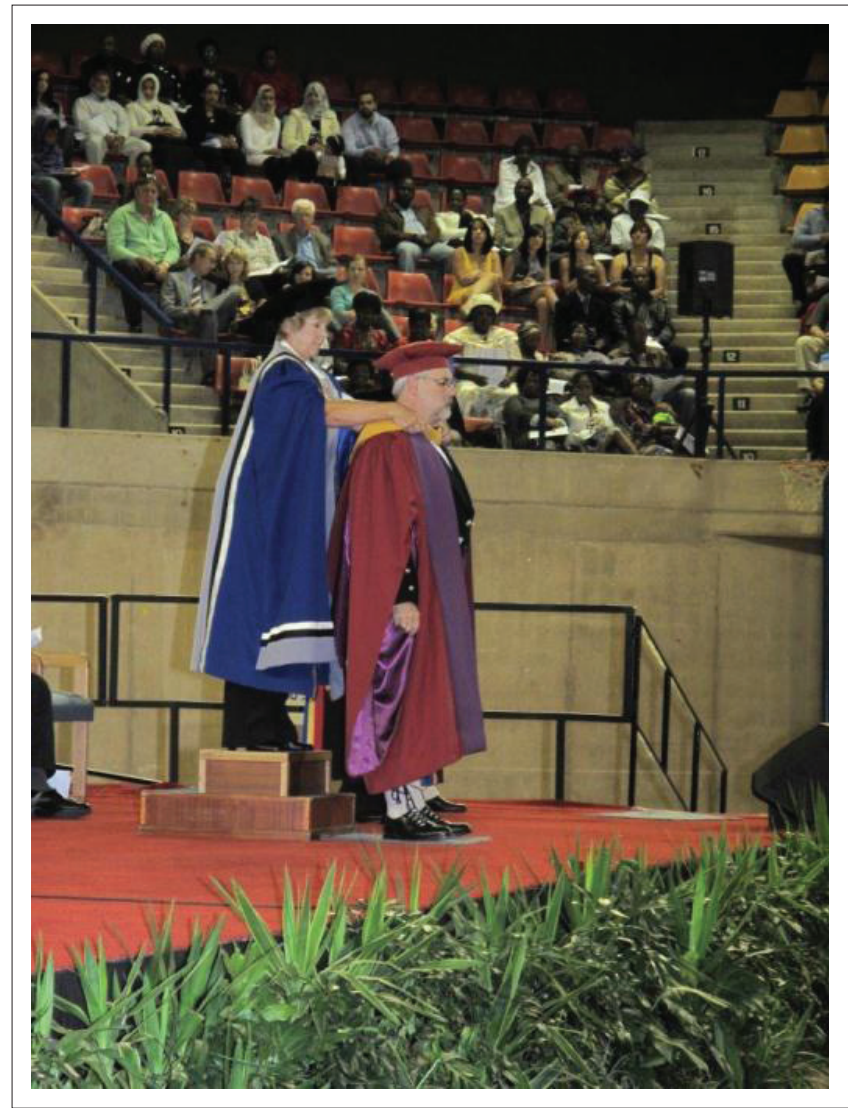

Source: Courtesy of Ms Annalize Brynard, Marketing Division, Faculty of Education

FIGURE 1: The narrative of his Postgraduate Certificate in Higher Education journey: attending the graduate ceremony.

indeed custodiet ipsos guardians. He excelled as mentor and received accolades relating to his innovative teaching practice. He, inter alia, was chosen by the students of the faculty as the best lecturer in 2013. He shared this enthusiastically (typical of him) with me in an email on 26 May 2014 - not as a self-accolade but as an acknowledgement of the impact of the PGCHE on his educational-professional development:

Dear Pieter,

More evidence of the success of the PGCHE!

I was elected best lecturer in Theology for 2013 by the student body last week!

Cheers!

Graham

His scholarly formation as academic represents the principles expected of contemporary educational-professional development opportunities he engaged from an intrapersonal point of departure. He opted for becoming a life-long learner and embraced scholarship of teaching in a selfregulated fashion - evidence of a metacognitive stance on his educational-professional development. This requires greater adaptability, critical evaluation and innovation as integral factors in teaching practice.

In terms of adaptability, the theory on whole brain learning that in its application entails accommodating students

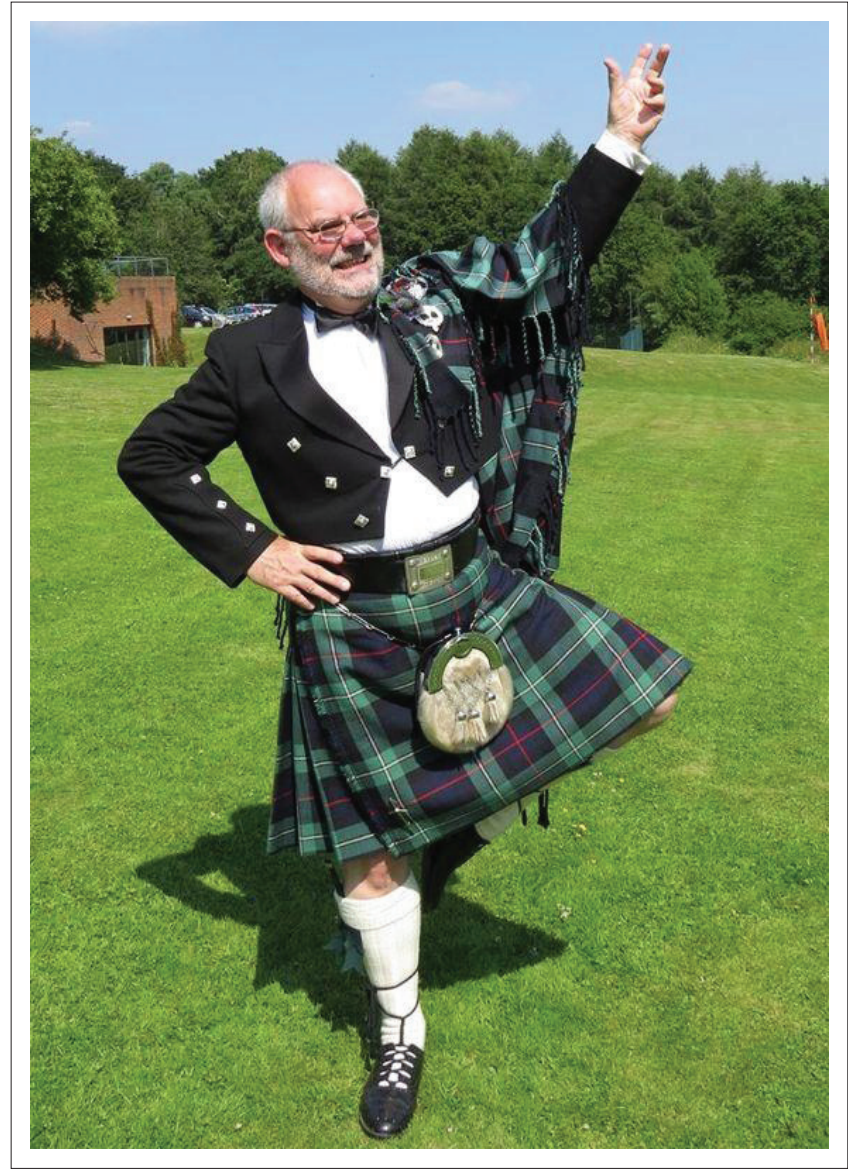

Source: Courtesy of Prof. Graham Duncan

FIGURE 2: The narrative of Prof. Dunan's zest for life in general and his academic career in all its dimensions.

according to their thinking preferences (De Boer et al. 2013; Du Toit 2013; Herrmann 1995, 1996) became prominent. As an individual, Graham Duncan has his preferred ways of solving problems and executing tasks. Tasks pertaining to his teaching practice that had to be executed - such as facilitating and assessing learning - challenged him in terms of adapting. He realised that he could not facilitate learning and assess student learning in ways he preferred and had been used to in the past. He indicates that, as someone with a preference for logical, fact-based and rational thinking and being in control, organised and methodical he realised that he was not accommodating students with thinking preferences other than his. He had the following to say in this regard:

Teaching had become boring for me and uninteresting. This was doubtless true of my students also. Reflecting on this led me to realise the significant role of passion in assessment/selfassessment. Without it teaching and learning becomes sterile and boring. The need for change was evident and spurred me on to look for alternatives. I had imposed my own teaching and learning preferences on my students regardless of their learning preferences. I thought I had been supportive but was sometimes actually being obstructive. I came to realise that by constantly reinforcing my own learning style to the exclusion of others, I was denying myself a valuable source of insight and support. I was a loner in terms of learning style and was not comfortable with group learning. It was a novel approach, foreign to my own methodology. I wasn't opposed to it as I advocated it for students who were comfortable with it but I was not comfortable with it. 
This has enabled me to integrate a new personal model of teaching and learning into my practice. I was also required to participate in group work in the course module on Curriculum Development [referring to the PGCHE] which challenged and enervated me.

To address this concern, the following idea that I coined became relevant: He had to start 'thinking out of his box'. He had to unlearn some of his ways of doing of the past and had to become more diverse in designing and offering learning and assessment opportunities - something he acknowledges in the quote above.

Analogue to the ideas that Graham Duncan expresses in terms of ministerial candidates, he journeyed on a path to deeper knowledge and experience of teaching in higher education context - a life-long learning of higher education, especially in terms of practice. This is a novel way of expressing the constant (semper reformanda) transformative process (Duncan 2010) of disciplining others. Further, it concurs with the active constructivist learning approach in which professionals (as students) construct knowledge for themselves and that there is no knowledge independent of meaning attached to experience (constructed) by the professional (student), or community of practice (Von Glasersfeld 2001). It also aligns well with the process of action research (Du Toit 2014) that is experimental - with a focus on implementing innovative ideas in practice - and that is constructivist in its epistemology. It is a process of reflection and meta-reflection on one's own teaching practice in which the lecturer adopts an insider perspective - practitionerresearch as proposed by McNiff and Whitehead (2006). This makes it different from traditional research as it becomes living theory and a process of new meaning making.

\section{Constructivism}

\section{Constructivist professional}

As a teaching and learning model, Graham Duncan adopted a constructivist approach to his facilitating of learning. He focused on what the students were supposed to do within their own context and in relation to their differing real-life challenges to which Slabbert et al. (2009) refer. He departed from the premise that his constructivist approach to his teaching practice is grounded in four epistemological assumptions adapted from Gagnon and Collay (s.a.), namely that new meaning making is:

- Physically constructed by students who are involved in active learning

- Symbolically constructed by students who make their own representations of action

- Socially constructed by students who share their meaning making with others

- Theoretically constructed by students who try to explain things they do not completely understand.

He considers this as essential for his theological education context. To him it means that students actively engage in a collective learning process. To him it also means that they engage in their respective individual learning processes - as a means to constructing own new meaning. Own meaning making is an attribute of the 21st century all professionals ministers and academics alike - should have. Such meaning making is evident in the scholarly work Graham Duncan has created and his application of principles of innovative learning theories in practice. As a proponent of constructivist learning, he lived the assumptions referred to above as a student enrolled on the PGCHE. This claim is substantiated by the action research of the teaching practice he executed. The broader context of action research facilitates constructivist educational professional learning in that it is reflexive and provides an iterative experiential learning cycle (Kolb 1984) for continuous and life-long learning that is situational, collaborative, participatory, self-evaluative, interpretative, critical, practical and theoretical (Hodgkinson \& Maree 1998).

Within the designated area of ministerial and spiritual formation, the curriculum development model used at the University of Pretoria operates in the academic environment at the micro- (individual lecturer), meso- (departmental and/ or church) and macro- (faculty) levels with the production of appropriate study manuals, learning programme documents and qualification templates to demonstrate the links between them in the overall programme design. In the same way, the curriculum design of the PGCHE and continuous curriculum development, which I initiated and for which I am responsible in a synchronistic fashion, informed his involvement in curriculum development activities and implementation. Professor Duncan's curriculum implementation included his wish to focus on meaning making rather than skills development. According to his view, the primary focus in the field of Practical Theology (theology of ministry) is the meaning making that informs practice, which he equates with deep learning and deep meaning - with its expectations of assessing in a different, novel fashion. Within the PGCHE, this was the expectation as he was to show evidence of making new meaning of an array of educational aspects within the context of higher education with a view to contributing to the current body of knowledge. This is part of his scholarly journey - a process aimed at deep learning that seeks deep meaning through engagement in order to achieve understanding and application rather than breadth of knowledge (Gibbs 1992; Gravett 2004). One of the real-life challenges of the PGCHE was to design a study manual for a module - one of the roles of a lecturer to be enacted. At the time, Professor Duncan was responsible for designing a new module and this coincided with this challenge.

In the curriculum development model used by the University of Pretoria (cited in De Boer et al. 2013), each lecturer is responsible for curriculum development at a micro-level. An important ingredient of a curriculum is the learning outcomes that are formulated and that are used to guide a lecturer's assessment practice. Overarching outcomes, referred to as critical cross-field outcomes and specific learning outcomes, are to be included in study manuals. The critical cross-field outcomes as outlined by the South African Qualifications 
Authority (SAQA) (SAQA 2002) are a set of outcomes that reflect the competencies expected of all graduates when they enter the real-life world of work. These represent the graduate attributes of the 21st century. Professor Duncan reported that he included some of the outcomes that would be applicable to the professional development of ministers. As part of the self-enquiry of his practice, he came to realise that aligning some of these critical cross-field outcomes with a teaching model that would be appropriate for the formation of ministers was essential. Students were expected to do the following:

- Reflect on their own understanding of ministry and what makes up a good process for vocational development and use a variety of strategies to become an able practitioner

- Solve problems presented in practice, in class or through observation and/or participation, using critical and creative thinking

- Work collaboratively with other congregational leaders to develop ministry within the concept of the 'priesthood of all believers'

- Collect, analyse, organise and critically evaluate information regarding ministry practice and own practice

- Communicate effectively as a congregational facilitator of learning (working towards ordination as a minister and/ or teaching elder) using a variety of media for preparing material and reports

- Reflect on the process and its value for personal development.

Another significant assessment opportunity in the PGCHE was the challenge to draft an article based on the action research of his teaching practice; this was a distinctive way of deep meaning making. Professor Duncan acknowledges the fact that the execution of his action research process of meaning making is consonant with reflective praxis. As with his own professional development as lecturer, which was based on engagement, he developed a model for ministry practice that would expect his students to experience what he was learning on the PGCHE in a synchronous way. He refers to action research as an iterative and helical (Wolvaardt 2013) process congruent with the notion of semper reformanda mentioned above.

\section{Constructivism as praxis and process}

Another real-life challenge (Slabbert et al. 2009) posed to Professor Duncan was to investigate the transforming of his practice. This real-life challenge expected him to take reflective action - a practice informed by theoretical reflection; or, conversely a theoretical reflection informed by practice. The construct praxis is significant as it attempts to keep theory and practice together as dual and mutually enriching moments of the same intentional ontological stance.

The aim of his constructivist educational approach was to design a model for the education of the whole person in the Christian faith ministry. He opted for applying the principles of action learning - expecting students to learn by going through cycles of planning, executing the plan, monitoring the execution of the plan, reflecting on their learning and evaluating the outcomes. In this way, he promoted change in personal practice. Working with his students as prospective practitioners enabled a mutual critique of current practice with a view to transforming practice. He aimed at promoting a constructivist approach to learning through critical reflection, ethical action and imaginative creativity as a foundation for individual and social praxis. Ethical action, for example, can be considered the justifiable claims (McNiff \& Whitehead 2006) we make regarding transforming of practice. The basis of the ethical claims he made was his acknowledging of the fact that praxis can only be valuedriven when it is built on the premise that his academic responsibilities had to take the multicultural diversity (Derek Bok Center 2004; Du Toit 2014) of the South African higher education context into consideration.

Claims that Professor Duncan made are the outcome of continuous critical reflection. In the document he compiled, he refers to the following important aspect of reflecting on practice: 'This will necessarily involve some self-critical analysis of personal and professional practice with the focus on personal change within the parameters of one's own church tradition'. This remark is also an indication of his ontological stance.

Next, the voice of Professor Duncan is heard as an epilogue - covering the last pages of this article. It is an anecdote of his reflection on what he practically implemented, narrated in the past tense:

An examination of a constructivist approach to teaching led me to realise a number of significant things in my teaching practice. In self-assessment I prepared well and was using a strong teacher tell approach, partly because there was so much material to cover and this tended to dominate my approach. I needed to try out small group methods to achieve greater involvement... [and self-assessment by my students] ...

Discovering the multifarious roles of educators reminded me that the teacher is often placed in the same role as the minister of religion who is expected to be a 'Jack of all trades', which often places an unfair burden on the teacher who sees her role in a more restrictive sense, especially the well experienced practitioner. One way of overcoming this would be by means of group or team teaching where general practitioners with specific skills might take responsibility for specific areas, e.g. community engagement. I had become too used to my solo approach but have begun to appreciate other students' [peers enrolled on the PGCHE] contribution to my personal development....

All my assessment was intellectually defined and I realised that this posed problems for students whose disadvantaged background might have been inhibited by this. I needed to devise flexible assessment tools to include all quadrants of Herrmann's whole brain model.

This relates directly to the rationale for action research beginning with myself. I was comfortable with style [sic] but realised the potential for myself and my students by expanding this approach to include action-driven approaches and deep learning linked to my role as a researcher. Recognising that education is a life-long process for lecturers and students provided a new relational 
context for teaching and learning (intrapersonal development) along with a new definition of leadership in education.... So we were on the same page learning together. Our discussions were lively and enjoyable. I was more relaxed and so were the students....

A good relationship was developing between myself and the class ... There was less tension about attendance and student input was improved in terms of content and timeous submission of work. I enjoyed the class better and I thought the students were too as far as I could assess. This mutual buy-in to the class project had been successful....

The relationship between lecturer and student is also a significant factor in learning particularly as the lecturer is the facilitator in the zone of proximal development (cf. Vygotsky 1978).

I also liked ... Schön's $(1983,1987$...) notion of being a 'reflective practitioner' with its 'reflection-in-action', 'reflection-on-action' [and] 'reflection-for-action'. The last mentioned is important for a praxis-based model....

And consequently, 'critical reflection on experience can expose some taken-for-granted assumptions' through iterative (repetitive and incremental) reflection. This would depend on building self-confidence and self-esteem and would be enhanced by such reflection for self-assessment is a reflective activity.

\section{Conclusion}

The conclusion of this article is dual in purpose. Firstly, Professor Duncan concludes his self-reflection on practice; secondly, I offer an overarching conclusion of the ethnographic study reported.

\section{He has the following to say:}

Action research is particularly helpful in the integration of theory and practice. An interactive constructivist approach has brought new life to the teaching and learning experience and is more enjoyable. There has been increased learner interest and involvement in their own formation and development. Problem solving skills are developed producing a 'positive impact on personal, attitudinal, moral, social, and cognitive outcomes' (Bringle \& Hatcher 1996:223)

The aim ... has been to enable learners and facilitators to discover ways of learning about the praxis of ministry through participating in their own learning process. Prior experience will provide a significant part of the resources for learning and additional material will be used to stimulate and develop their critical thinking abilities through using the action research approach with the aim of increasing knowledge, understanding and developing practice. This will require engaging in the practice of exacting planning, implementation observation and assessment. Taking account of the fact that ministry is a life-long teaching and learning exercise, the principle of life-long learning through action research is vital.

My conclusive remarks: Adequate evidence of self-enquiry into the teaching practice of Professor Duncan is offered in this article. It includes the reporting of his journey of educational-professional development. He passionately and honestly applied the principles of relevant learning theories studied as part of the PGCHE and from other professional development opportunities in practice. In addition, he introduced and extrapolated the same principles to his students' professional ministry formation - ensuring that they became constructivist, self-regulated professionals who can monitor their own professional life-long learning. This has been done, amongst other approaches, by means of using the process of action learning.

I consider Professor Duncan a constructivist scholar of teaching. His contribution in terms of new meaning making and contributing to our current understanding of higher education praxis is commendable. My scholarly view of higher education praxis in particular was enriched through my engaging in conversations with him and reading his work.

This ethnographic account is, however, not an accolade to the people in question - subjects of the research - but a deep understanding and acknowledgement: creabunt scientiam divinitus inspirata (creation of knowledge is inspired by God).

\section{Acknowledgements}

Financial assistance from the National Research Foundation (NRF) for projects 90387 and 00754 is hereby acknowledged.

\section{Competing interests}

The author declares that he has no financial or personal relationships which may have inappropriately influenced him in writing this article.

\section{References}

Babbie, E.R., 2013, The practice of social research, Wadsworth, Belmont, CA.

Bringle, R.G. \& Hatcher, J.A., 1996, 'Implementing service learning in higher education' The Journal of HigherEducation 67(2), 221-239. http://dx.doi.org/10.2307/2943981

Christensen, L.B., Johnson, R.B. \& Turner, L.A., 2014, Research methods, design, and analysis, Pearson, Boston, England.

De Boer, A-L., Du Toit, P.H., Scheepers, D. \& Bothma, T., 2013, Whole brain learning in higher education: Evidence-based practice, Chandos/Elsevier, Oxford.

Department of Education, 2002, Norms and standards for educators, Government Printers, Pretoria.

Derek Bok Center, Harvard University, 2004, Teaching in racially diverse college classrooms, viewed 27 November 2015, from http://bokcenter.fas.harvard.edu/ docs/TFTrace.html

Duncan, G.A., 2010, 'Church discipline: Semper reformanda as the basis for transformation', Journal of Theology for Southern Africa 136(March), 57-75.

Du Toit, P.H., 2012, 'Using action research as process for sustaining knowledge production: A Case study of a higher education qualification for academics', South African Journal of Higher Education 26(6), 1216-1264.

Du Toit, P.H., 2013, 'Social transformation starts with the self: An autobiographical perspective on the thinking style preferences of an educator', South African Journal of Education 33(4), 1-12. http://dx.doi.org/10.15700/201412171325

Du Toit, P.H., 2014, 'Innovating and transforming learning and teaching in higher education: Applying a comprehensive whole brain model', paper presented at the Edulearn conference, Barcelona, Spain, 7-9 July.

Gagnon, G.W. \& Collay, M. sa., 'Constructivist learning design', viewed 14 October 2010, from www.prainbow.com/cld/cldp.html

Gibbs, G., 1992, Improving the quality of student learning, Technical and Education Services Ltd, Bristol.

Gravett, S., 2004, 'Teaching and learning: Establishing communities of inquiry and interpretation', in S. Gravett \& H. Geyser (eds.), Teaching and learning in higher education, pp. 22-40, Van Schaik, Pretoria.

Herrmann, N., 1995, The creative brain, Quebecor Printing Book Group, USA.

Herrmann, N., 1996, The whole brain business book: Unlocking the power of whole brain thinking in organizations and individuals, McGraw-Hill, New York.

Hodgkinson, C.A. \& Maree, J.G., 1998, 'Action research: Some guidelines for first-time researchers in education', Journal of Education and Training 19(2), 51-65.

Kolb, D.A., 1984, Experiential learning: Experience as the source of learning and development, Prentice Hall, Eaglewood Cliffs, NJ. 
Kumar, R., 2014, Research methodology: A step-by-step guide for beginners, SAGE, Los Angeles, CA.

McNiff, J. \& Whitehead, J., 2006, All you need to know about action research, SAGE, London.

Mouton, J., 2001, How to succeed in your master's and doctoral studies: A South African guide and resource book, Van Schaik, Pretoria.

O'Leary, Z., 2014, The essential guide to doing your research project, SAGE, London.

Schön, D.A., 1983, The reflective practitioner: How professionals think in action, Basic Books, New York.

Schön, D.A., 1987, Educating the professional educator: Toward a new design for teaching and learning in professions, Jossey-Bass, San Francisco, CA.

Slabbert, J.A., De Kock, D.M. \& Hattingh, A., 2009, The brave 'new' world of education: Creating a new professionalism, Juta, Landsdowne Cape Town.
South African Qualifications Authority, 2002, National qualifications framework for curriculum development, SAQA, Pretoria.

University of Pretoria, 2015, Professional Development (PFO400) and Mediating Learning (PFO 400): Study manual, Du Toit, P.H., Pretoria.

Von Glasersfeld, E., 2001, 'Radical constructivism and teaching', Prospects 31(2), 161-173. http://dx.doi.org/10.1007/BF03220058

Vygotsky, L.S., 1978, Mind in society: The development of higher psychological processes, Harvard University, Cambridge, MA.

Wolvaardt, J.E., 2013, 'Over the conceptual horizon of public health: A living theory of teaching public health to undergraduate medical students', PhD thesis, Department of Humanities Education, University of Pretoria.

Zuber-Skerritt, O., 2000, Action learning, action research and process management: Theory, practice, praxis, Action Research Unit, Faculty of Education, Griffith University, Brisbane. 